\title{
Sustainable Management and Stakeholder Participation in Chilika Lagoon in Odisha in India
}

\author{
Smita ${ }^{1}$ and Shiau-Yun $\mathrm{Lu}^{2}$ \\ ${ }^{1,2}$ Department of Marine Environment and Engineering, National Sun Yat-Sen University, Kaohsiung 80424, \\ Taiwan
}

\begin{abstract}
Sustainable Management is a scientific principle that forms the basis of sustainable global resource management and environmental governance to conserve and preserve natural resources. It basically focuses on scientific and technical understanding of ecology and resources with its life supporting capacity. Stakeholder participation is a tool used as a social learning process with a platform to create awareness among the stakeholders in context of the proper resource utilization of a particular area. Moreover the participation of the stakeholders in terms of resource utilization is very recent tool in handling natural resource management. This paper examines the extent of stakeholder participation in the sustainable management of Chilika Lagoon. Around six hundred individuals were randomly selected for the study. The information was collected on the basis of a set of questionnaire having closed ended as well as open ones. This paper concluded that there was very little involvement of the stakeholders in the decision making for the conservation of the lagoon. But their interest in the resource utilization of the lagoon seems to be very high in terms of dependency. They also wanted to have a major stake in planning of the resources as they feel that the expertise lies with them. The use of resources is much of concern among the stakeholders who actually want to have a bigger role in decision making of the lagoon to maximize their profit from Chilika. To ensure the sustainable management process it can be said that there is a scope of broadening the base of interests groups in the decision making process of Chilika lagoon for its conservational aspects.
\end{abstract}

Keywords: Sustainable Management, Stakeholder participation, Lagoon conservation, Socio-ecological relations, etc.

\section{Introduction}

The concept of Community Based Natural Resource Management (CBNRM) has recently gained much of attention in the field of sustainable natural resource management. This calls for the larger participation of the community which is being encouraged by the state level to national and even international level resource agencies who are in supposition that local communities have the real attachment with the local resource. This is in regard to their affiliations, knowledge, and interests in the proximate resources and have all right to participate in the sustainable use of these natural resources. There is a wide range of natural resources such as fisheries, wild life, wetland, forests, land, ground water where the CBNRM approach has been very successful ${ }^{\circledR}$. This has been variously used in different aspects of ecological resources conservation from oriental to occidental areas. The growth of research on common pool resources in ecological disciplines during the last two decades has been found in market based incentives, decentralization of resource appropriation. It also amounts to great sense of synergy between ecological conservation, biodiversity preservation along with rural development. This can help to connect the local demands for greater control over the resources in having a say in political decision making for sustainable management of resources.

There is always an issue of pros and cons of any new approach. The approach has its use and misuse different in different spatio-temporal setting. The results cannot be same for different geographical regions. Some of the researchers like Rodary E. ${ }^{3}$ in his paper argued that it was not successful in the areas like subSaharan Africa. He describes that CBNRM has failed in respect of community participation, and lack of ecological results. Others criticized on the basis that community is not always a single entity and a cohesive group. This can be one of the limitations of the participatory approach to sustainable management of natural resource. However, in terms of practice in this globalised world new approach is always welcome. These approaches facilitate equitable distribution of scarce resources, and make more and more people accountable for

\footnotetext{
${ }^{1}$ PhD Student, Department of Marine Environment and Engineering, NSYSU, Taiwan

${ }^{2}$ Assistant Professor, Department of Marine Environment and Engineering, NSYSU, Taiwan

${ }^{3}$ Rodary E. Mobilizing Africa for southern African community based conservation policies or the death of local. Biodiversity Conservation 2009, 2585-2600.
} 
viable environmental outcomes. The CBRN approach to the stewardship to the natural resources has been has been found to be a viable alternative and if properly executed it can be more effective for proper distribution of resource benefits and improve upon resource conflicts. This can be the best tool for consideration of the modern and the traditional environmental knowledge which can help in protection of the biological diversity and sustainable utilization of natural resources.

Interestingly, the variation in the scope and context of the approach gives it extra added advantage for further research. The social, ecological, political, institutional dimensions of CBNRM help in decentralized nature of governance. In some of the cases like high value natural resources are generally owned by the State or the institutional agents. These are tied to high level of corruption; they form strong level of disincentive for the central authority to delegate powers to the local authority. The very basics of natural resource management in relation to the development of the locality and associated livelihoods with multi-functional nature of the land are given prominence. As in case of Africa from northern desert area the variation continues to the southern coastal area. Whereas, CBNRM approach in context of the developed countries viz. USA, Canada, Switzerland etc have also emphasized the need to focus on the definition of the communities and thereby need to focus on the participation formed by the institutions. As in case of Australia, New Zealand, Taiwan, Japan, and Korea the coastal countries have different socio-political and environmental change for different scenario. In respect of the ongoing debate I want to continue with the CBNRM approach in Coastal lagoon area. In particular this paper focuses on Chilika lagoon in Odisha in India.

Coastal lagoon is a dynamic ecosystem rich in bio-diversity which supports exploitable fisheries which provide food for large scale human population. Phelger (1969) defined coastal lagoon as, "shallow inland marine waters usually oriented parallel to the coast, separated from the oceans by one or more number of restricted inlets." Day (1980) has shared the views with Pritchard (1967) that coastal lagoons are also a type of estuary and defined coastal lagoons as "A partially enclosed coastal body of water, which has either permanently or periodically opened into the sea, and within which there is measurable variability of salinity due to admixture of seawater and freshwater derived from inland drainage". This definition is important as it includes a variety of coastal water bodies viz. estuaries, coastal lagoons, saline lakes, small inlets of the seas etc., even though they possess different geomorphologic attributes.

Geographically the coastal lagoon is starched from arctic to the tropics (Nicholas and Boon, 1994), covering $13 \%$ of the coastal region of the world may be ranged from $<0.01 \mathrm{~km}^{2}$ to $>10000 \mathrm{~km}^{2}$ (Bird, 1994; Kjerfve, 1994). The most scientific definition ever on coastal lagoon is by Emery and Stevenson (1957), "coastal lagoons are the bodies of water, separated in most cases from the ocean by offshore bars or islands of marine origin and are usually parallel to coast line". But considering the overall salient features of lagoons Pritchard, (1967) says that lagoons can also be treated as estuaries. Estuary is a semi-enclosed coastal body of water which has free connection with the open sea and within which the sea water is measurably diluted with the fresh water derived from land drainage. This definition I suppose may not be very true as lagoons are periodically or permanently cut off from the sea. So Pritchard (1967) again says that, lagoons are partially enclosed body of water which has either permanently or periodically opened into the sea and within which there is measurable variability of salinity due to admixture of seawater and freshwater derived from inland drainage".

Lagoons are very intricately linked to the natural environment which helps them to develop the functional and structural regulations for the sustainable resource management and their biological diversity. These days care has been unseen for the natural lagoons which are on the verge of degradation due to overexploitation of the natural resource capital. Chilika Lagoon is one of the distinctive examples. Chilika has been in news for its big restoration and sustainable management applications. This also represents a big success story of the Ramsar sites in consideration. But there have been some of the loopholes in managing the decision makers or to say the real stakeholders which have given Chilika again to visualize the real scenario. To foster the sustainable management of the lagoon proper knowledge and information in a coordinated manner is important to enable the decision makers. The real task is to identify the appropriate choices that affect the lagoon ecology. These decisions and centers on finding the resources of the lagoon and the socio-economic relations associated with it. However, it is of vital importance to establish a plan or the process which will provide consistency and will ensure coordination regarding the present and the future of the Lagoon. These may include the indigenous ecological knowledge to include the local communities and their institutions in a participatory manner. The paper also extends in the line of work in promoting community participation in the sustainable resource management of the lagoon along with its restoration and ecosystem governance. These combine the diverse ecosystem knowledge in sustainable management of socio-ecological system. The paper will specify the context and extent of the participation by the stakeholder in the sustainable management of resources in Chilika along with pragmatic solutions and approaches. 


\section{Participatory Ecosystem Management}

Participatory ecosystem management is the offshoot of the principle of sustainable management with a view to protect the ecosystem in a given environment. This is a pie chart of ecological, biological and anthrogenic which is integrated to interact and exploit each other in a system to have an impact on the systems of each component. The management of ecosystem involves multidimensional facets such as political, social, and economic while these may also include stakeholder which involves the fishermen, local population, land owners, environmentalists, politicians, industrial groups etc. So the ecosystem management of a lagoon go through multi-criteria of the decision making process. The basic elements and principles of the participatory sustainable management are as under:

1. There should be multiple use of region within a specified legal framework with long term management i.e. indicative management principle.

2. There should be all sectoral involvement with the collaboration of all stakeholders and the interests groups.

3. There should be proper framework for the aims and objectives of the local community and their aspirations.

4. There should be appropriate channelization of the scientific principles and tools involved in the sustainable management approach.

5. The definitions of the goals set are based on the sound ecological principles and its understanding.

6. All the components and character of the ecosystem should be in context and scale with full adaptability.

\section{Materials and Methods:}

Chilika is situated between the latitude of $19^{0} 28^{\prime}$ to $19^{0} 54^{\prime}$ north and the longitude of $85^{0} 05^{\prime}$ east. The total extent of Chilika varies seasonally according to the prevalence of the monsoon. In the monsoon season the area of Chilika is $1165 \mathrm{sq} \mathrm{km}$ while in the non monsoon season it is squeezed to $906 \mathrm{sq} \mathrm{km}$. Similarly the average depth of Chilika varies from 1.73 to 3.7 meters during the rainy season and 0.93 to 2.6 meters during the non rainy or summer season.

Map 1. Chilika lagoon and its Location.

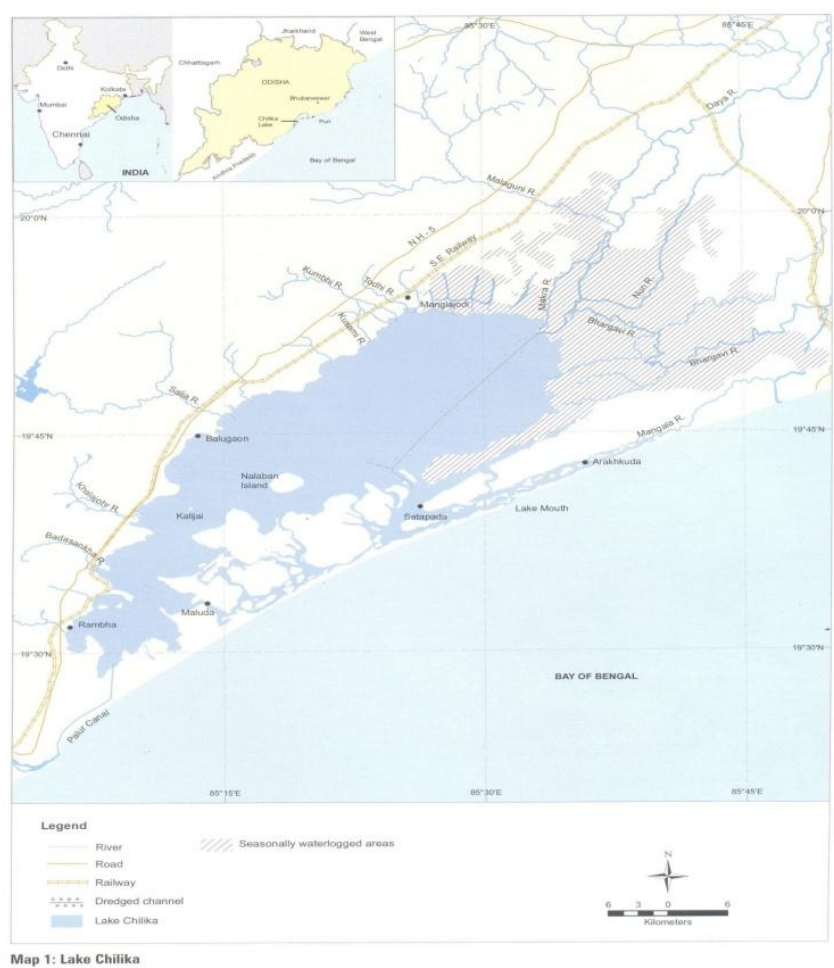

Source: The Atlas of Chilika 2001

Originally Chilika had one mouth at it southern end. At present it has three mouth openings into the Bay of Bengal. The first one is called Maggarmukh near the village Arakhada, the other is Palur and third one is the new mouth opening in the Sipakuda village by Chilika Devlopment Auhority (CDA) in September 2000. The opening called the Maggarmukh has become shallow with time due to siltation brought by the rivers namely, 
Bhargavi, Daya and several other distributaries of the Mahanadi River. Geographical division of Chilika is into four major sector viz., northern zone, central zone, outer zone and Southern zone. The northern sector which receives direct discharge from the major river Mahanadi has its delta predominantly with the freshwater characteristics. The central sector is mixed water with both freshwater and brackish water characteristics. The southern sector is the deepest part of Chilika and has higher salinity level as compared to central sector because of the influence of Rishikulya estuary. In the outer channel which is towards the seaward side is the area of water exchange between the lake and the sea. The unique characteristic of Chilika brings it to have a very rich biodiversity. This includes 314 types of fishes, 224 species of water birds including 97 intercontinental migrants and 729 species of angiosperms with several of economic value. The lake hosts over one million wintering migratory birds. It is also one of the few lagoons in the world that support Irrawaddy Dolphin (Orcaella Brevirostris), Barkudia insularis, a limbless skink which is endemic to Chilika. Chilika is visited by 0.3 million domestic and foreign tourists each year.

\subsection{Data Collection:}

Approx six hundred individuals from 27 stakeholder group were randomly selected for the survey. Questionnaire and the face to face interview were the major tools employed in the study. The questionnaire in the interview for the stakeholders was open -ended and closed type. The approach of the paper is qualitative. This approach included participant observation with some analysis to validate the responses of the qualitative approach.

The time period of the interview was June 2009-August 2009 to ascertain the individuals and the stakeholders. The major themes were related to the derived income, sources of livelihood as well as their impact on the lagoon. The major dependency of the people of the area is basically cultural, scientific, tourism, industry, commercial fishing, livestock, agriculture etc. This was the conclusive of the six hundred samples taken for the study. The statistics applied were also dependent on the Likert Scale of bi-polar responses of the involved respondents. This was done on respondent's awareness of the sustainable participatory ecosystem management where the different stakeholder group responded about the elements of the ecosystem of Chilika lagoon.

\subsection{Demographic Information}

Demographic information is the essential key in the paper presented here. The present survey included gender, age, education, occupation and their rights on the resources of Chilika lagoon. The age group varies between 18 years (which is the adult age considered as for voting right for Indian male) to 60 years. This age group was well managed as I gathered all of the in the centre of the village and distributed the set of questionnaire. There was great variation in responses of the males and females. The females of the village were mostly involved in their household work so even the participation was very less. Only $21 \%$ of the females responded in contrast to $79 \%$ of the males.

Table 1. Number of stakeholders with their gender, age and occupation.

(Maximum stakeholders from Village Chilika from Central Sector)

\begin{tabular}{|c|c|c|c|c|c|}
\hline $\begin{array}{l}\text { Name of the village } \\
(\text { Central Sector- } 40)\end{array}$ & Number & Male & Female & $\begin{array}{l}\text { Age } \\
\text { Group }\end{array}$ & Occupation \\
\hline Banpur & 16 & 13 & 3 & $40-45$ & Fishermen, Clan head \\
\hline Bhimpur & 8 & 7 & 1 & $28-40$ & Fishermen, Elderly \\
\hline Bidharpur & 8 & 6 & 2 & $35-50$ & Fishermen, Clan head \\
\hline Galua & 8 & 8 & - & $40-50$ & Fishermen, Religious head \\
\hline $\begin{array}{l}\text { Balugaon } \\
(292)\end{array}$ & 80 & 65 & 15 & $25-50$ & Fishermen, students \\
\hline Haripur & 80 & 57 & 23 & $25-42$ & Non-fishermen, traders \\
\hline Nimikheta & 120 & 97 & 23 & $22-52$ & Fishermen, non-fishermen \\
\hline $\begin{array}{l}\text { Krishnaprasad } \\
(56)\end{array}$ & 4 & 4 & - & $30-42$ & Farmers, fishermen \\
\hline Berhampur & 4 & 4 & - & $30-40$ & Localites \\
\hline Gomundei & 4 & 4 & - & $25-35$ & Fishermen, non-fishermen \\
\hline Nuapada & 16 & 10 & 6 & $30-40$ & Fishermen \\
\hline Siandi & 8 & 6 & 2 & $25-45$ & Fishermen \\
\hline Alanda & 8 & 5 & 3 & $28-45$ & Farmers \\
\hline Khatiakudi & 8 & 7 & 1 & $24-50$ & Fishermen, non-fishermen \\
\hline Badaanlo & 12 & 10 & 2 & $30-40$ & Fishermen and farmers \\
\hline $\begin{array}{l}\text { Ganjam and Khalikote } \\
\text { (Southern Sector-224) }\end{array}$ & 40 & 40 & - & $20-45$ & $\begin{array}{l}\text { Small workers of } \\
\text { workshops }\end{array}$ \\
\hline Ramgarh & 14 & 7 & 7 & $35-45$ & $\begin{array}{l}\text { Fishermen and tourist } \\
\text { occupationers }\end{array}$ \\
\hline Khalikote & 40 & 40 & - & $25-55$ & $\begin{array}{l}\text { NGO authority and Elderly } \\
\text { people }\end{array}$ \\
\hline Pathara & 20 & 20 & - & $28-38$ & Masons and non -fishermen \\
\hline Keshpur & 120 & 102 & 18 & $35-45$ & Fishermen and Farmers \\
\hline Kanka & 30 & 8 & 22 & $30-45$ & Factory workers \\
\hline
\end{tabular}




\section{Results and Discussion}

It is important to take account of all the stakeholders in the process related to lagoon for better outcome in the quality decision of the lagoon decision making. According to the survey conducted $5 \%$ of the people said that they do not use the resources of the lagoon at all, $10 \%$ said they do seldom, $25 \%$ use very less while $60 \%$ of the population are frequent user of the lagoon. These $60 \%$ of the population does not think about the sustainable use of the lagoon at all while the rest $40 \%$ were aware but did not do anything, only $25 \%$ of the population tried. The main reason is the lack of awareness among the people living over there. The participation of the stakeholders can be categorized as primary or secondary or active or inactive. Primary stakeholders mean the direct beneficiaries of the Chilika lagoon or its associated features like its resource effects such as the local fishermen. We can divide the primary stakeholders in terms of social and economic class, gender, and occupation. Secondary stakeholders may not be direct beneficiaries like fishermen but may be referred as advocate for the betterment of the lagoon area such as the civil society. These can be government, NGO's, monitoring, funding and implementing agencies like Chilika Development Authority, etc. This may also include some elderly people of the society, politicians and religious influential persons. We can have a table related to different stakeholders of Chilika categorized into various sectors.

Table 2: Different stakeholders and their interests in Chilika

\begin{tabular}{|c|c|c|c|c|}
\hline $\begin{array}{l}\text { Stakeholder } \\
\text { Group }\end{array}$ & $\begin{array}{l}\text { Features and } \\
\text { Characteristics }\end{array}$ & $\begin{array}{l}\text { Passive/ Active } \\
\text { Dependency }\end{array}$ & Use of Resource & Interest in Chilika \\
\hline Fishermen & Primary stakeholder & Direct & Utilization of fish, & $\begin{array}{l}\text { Harvesters of fishes of } \\
\text { lagoon }\end{array}$ \\
\hline $\begin{array}{l}\text { Elderly People } \\
\text { with religious } \\
\text { values }\end{array}$ & Secondary stakeholder & Indirect & $\begin{array}{l}\text { Little use of resource } \\
\text { of lagoon }\end{array}$ & $\begin{array}{l}\text { Help in preserving } \\
\text { cultural values of } \\
\text { lagoon }\end{array}$ \\
\hline $\begin{array}{l}\text { NGO's and other } \\
\text { Local groups }\end{array}$ & Secondary stakeholder & Indirect & Little use of resource & $\begin{array}{l}\text { Help in ecological } \\
\text { maintenance }\end{array}$ \\
\hline $\begin{array}{l}\text { Business Groups } \\
\text { and Tourism } \\
\text { Involvement }\end{array}$ & Primary Stakeholder & Direct & $\begin{array}{l}\text { Involved in } \\
\text { recreational centres, }\end{array}$ & $\begin{array}{l}\text { Helps in tourism } \\
\text { industry and Trade } \\
\text { inputs }\end{array}$ \\
\hline $\begin{array}{l}\text { Media } \\
\text { ( Electronic, } \\
\text { digital, social) }\end{array}$ & Secondary stakeholder & Indirect & Overall watchdog & $\begin{array}{l}\text { Helps in promoting } \\
\text { awareness }\end{array}$ \\
\hline Marginal Farmers & Primary stakeholder & Direct & $\begin{array}{l}\text { Irrigational use of } \\
\text { water }\end{array}$ & $\begin{array}{l}\text { Other resource intake in } \\
\text { farming }\end{array}$ \\
\hline $\begin{array}{l}\text { Government } \\
\text { agencies and } \\
\text { departments }\end{array}$ & Secondary stakeholder & Indirect & - & $\begin{array}{l}\text { Takes care of the policy } \\
\text { sector }\end{array}$ \\
\hline $\begin{array}{l}\text { International } \\
\text { Agencies }\end{array}$ & Secondary stakeholder & Indirect & - & $\begin{array}{l}\text { Maintain global support } \\
\text { for the lagoon }\end{array}$ \\
\hline $\begin{array}{l}\text { Researchers in and } \\
\text { around Chilika }\end{array}$ & Primary stakeholder & Indirect & - & $\begin{array}{l}\text { Research and training } \\
\text { support }\end{array}$ \\
\hline $\begin{array}{l}\text { Residents around } \\
\text { the lagoon }\end{array}$ & Primary stakeholder & Direct & Fisheries and Farming & $\begin{array}{l}\text { Takes care of socio- } \\
\text { economic benefits }\end{array}$ \\
\hline $\begin{array}{l}\text { Central } \\
\text { government }\end{array}$ & Secondary stakeholder & Indirect & - & Environmental health \\
\hline
\end{tabular}

Based on various needs, aspirations and resource use of Chilika lagoon we can say that sustainable use of lagoon management involves stakeholder participation. There has been a long silence in the management of lagoon resources. There have been few committees and few rules written here and there very informally which has been hurdle to enforce any law in this area. Practically if we see the fishermen goes for fishing in morning and late afternoon times because evening is generally the time of bad weather because of eclipses. The rest of the time is for the professional stakeholders those who have the legal and the informal right over fishing. This particular culture of neglected timing and area for fishermen is passively seen by all other indirect stakeholders. There has always been conflict in sustainable use of conflict of resources mainly because of regulation of the management authority which can help in the breakage of silence of the negligence of nature and its dependents. The misappropriation and the misutilisation of the resources have put the primary stakeholder at the back seat. According to the fishermen there have been no proper laws of the lagoon mentioned in any paper put forwarded by the policy makers. There should be concept of equitable distribution of the fisheries available for the entire stakeholder. There has been voice raised for the primary stakeholder by some of the local NGO's and groups who are really concerned for sustainable management of the resources in Chilika. One of the fishermen indicated,

"We are unable to catch hold of fishery in the lagoon now as there has been geris made by the professional prawn culture who are the law makers and also the law breakers of this land." 
The residents or the fishermen have the highest right to take on the resources of the lagoon. There has also been loss of information and the proper channel to pass on the information for the needed people. Here comes a tool which is helpful for the participatory management of the resources and fills the communication gap among the several stakeholders. There can be made community representatives who can be ideal individuals for different communication purposes. The main problem is that the resident people are not aware of the participatory management methods. So there is a strong need to broaden the base of the stakeholder participation for sustainable management. This participation should be concentrated on the issues such as fishing, agriculture, livestock, aesthetics, tourism, recreation, aquaculture etc. The different stakeholders those who are interested in the participatory management of the lagoon do not have information and the scope to get involved in the management process. The real challenge is the lack of information and awareness that this concept of participatory management will help in filling up the communication gap and will help in making better arrangements for the rest of the stakeholders. Some of the secondary group of stakeholders are also not constant basically those who are indirect users of the resource of Chilika. These include the emerging entrepreneurs who are involved in shrimp culture inside Chilika lagoon. These are the investment group interested in having their economic benefits. This amounts to potential threat of resource conflict as they are influential and wealthy people who could manipulate the decisions of the law makers. So, here we may use the poor man's entertainment tool i.e. Radio (an electronic medium) to pass on the awareness message.

The above table shows that there is a very thin line associated among the direct resource users and the indirect ones. Indirect users are operational in far reach of the area while direct users are operational from nearby of the lagoon. So space is the real key. The direct users can be better and pragmatically opined in the decision making body. The stakeholders like fishermen, academicians, researchers, local authorities, elderly and religious people of the niche, etc can have actually needed outcomes which can have significant changes in the sustainable management of the lagoon. This goal is difficult but not impossible to achieve through the structures of decentralised government working at the grass root level. For this we need to understand the connection between the structure and the stakeholders involved in the process of management. The local body will have to take the flag of policy responses and intervene the stakeholder group wherever the participation is needed. But this intervention should be with the goal of fostering democratic values and empowerment for all sections of the society equally. The government at the centre and the state is least bothered for these people. Statement of few fishermen is as under:

"The government think that low literacy level is equivalent to lack of knowledge about the sustainable management of the lagoon. But they should not forget that we are the real harbingers of the resources of Chilika as this is our mother lake that takes care of us as her sons and daughters. Moreover, Chilika belongs to the indigenous people not the outsider's entrepreneurs."

This clearly reflects that there is a dearth of understanding in govt functionaries about the participatory approach in proper appropriation of the resources of lagoon. This is really a very big challenge posed to the local people but they will have to take care of their resource rights. For this these groups will have to select their representatives and send them to the decision making table to enable and articulate their goals and dreams. The survey indicates that the most vulnerable takers of the lagoon are the primary stakeholders i.e. the residents of the periphery. There is an urgent need for the social learning process with regard to the sustainable management through participatory approach. This will be done by effective communication platform (Provided by Chilika Development Authority, CDA) with mutual trust and collective effort of all the related stakeholders.

\section{Conclusion}

The lagoon Chilika needs to be explored more appropriately so as to manage the resources and help in strengthening the ecological harmony between lacustrine ecosystem and its dependents. The decision makers sitting far away may not be the right people to judge the system and functions of the lagoon so there is an urgent need to broaden the base of participatory role of the stakeholders for sustainable use of the resources. The policy makers must take holistic approach to arrive on a particular proposal for sensitive ecological sites such as lagoon. This is very much essential to reduce the risk of resource conflict taking care of all the stakeholders' interest to the best possible manner. The paper concludes that there is always a scope to broaden the base of participatory management to provide sustainability to en ecosystem. We ought to understand the grass root stakeholders participation to the top level also from horizontal to vertical scale. Community as a unit has bigger strength than an individual. So when these communities will have a say in making their own choices then the nearby resources would be automatically conserved for better future.

\section{Acknowledgements}

I heartily wish to express my sincere gratitude to Mr. Chitranjan Mishra, then person-in-charge of Chilika Development Authority who always extended his all kind of support needed for my paper and related work. I also wish to thank Wetland International for sharing their document. 


\section{References:}

[1]. Alkhafaji, A.F. A Stakeholder Approach to Governance: Managing a Dynamic Environment; 1989, Quorum Books: Westport, CT, USAChilika Development Authority. 2003. Achievement Report.

[2]. Bogart, M.V.D, 1992, Introduction. Saving Chilika Lake, Saving the people of Chilika, Xavier Institute of Management, Bhubaneswar.

[3]. Barnes R.S.K., 1980, Coastal lagoons. Cambridge: Cambridge University Press

[4]. Boulanger, P.M.; Brechet, T.2005, Models for policy making in sustainable development: The state of the art and perspectives for research. Ecol. Econ.

[5]. Clark, C.W; Dickson, N.M.2003, Sustainability Science: The emerging research program. PNAS.

[6]. Coastal Lagoons: Ecosystem Processes and Modeling for Sustainable Land Use and Development; 2005 Gonenc, E., Wolflin, J.P., Eds.; CRC Press: Boca Raton, FL, USA.

[7]. Ghosh, K. Ashish, Pattnaik, K. Ajit and Ballatore J. Thomas Chilika Lagoon: Restoring ecological balance and livelihoods through re-salinisation, 2006, Lakes and Reservoirs: Research and management.

[8]. Freeman, R.E. Strategic Management: A Stakeholder Approach, 1984, Pitman: Boston, MA, USA

[9]. Lenka S.K. (2002) An approach to the community based ecotourism planning for Chilika Lagoon,. Chilika Development Authority, Bhubaneswar, India

[10]. S.K. Mohanty, 1976, Further additions to the fish fauna of Chilika Lake, Journal of Bombay Natural History Society

\section{Websites}

[11]. Chilika Development Authority: http://www.chilika.com/

[12]. Ramsar Convention: http://ramsar.org/ 